\title{
NIGERITE FROM THE ROSENDAL PEGMATITE AND APLITES, KEMIÖ ISLAND, SOUTHWESTERN FINLAND
}

\author{
E. A. J. BURKE, P. LOF, and H. P. HAZEBROEK
}

\begin{abstract}
BURKE, E. A. J., LOF, P. and HAZEBROEK, H. P. 1977: Nigerite from the Rosendal pegmatite and aplites, Kemiö island, southwestern Finland. Bull. Geol. Soc. Finland 49 (2): 151-157.

Nigerite occurs as small hexagonal platy crystals in the Rosendal pegmatite and in associated aplitic veins on Kemiö island, southwestern Finland. This is the first reported occurrence of nigerite in the Baltic Shield. Associated minerals are quartz, hercynite or gahnite spinel, plagioclase, muscovite, sillimanite, garnet, columbitetantalite, chrysoberyl, tourmaline, apatite, corundum, Zn-bearing staurolite, and cassiterite. Nigerite has been formed under conditions of oversaturation of $\mathrm{Al}$ by desilicification of the pegmatite system. Microprobe analyses of the Rosendal nigerite were calculated by a general formula: $\mathrm{R}_{2-2 \mathrm{x}}^{2+} \mathrm{Sn}_{\mathrm{X}} \mathrm{R}_{4}^{3+} \mathrm{O}_{8}$, with $\mathrm{R}^{2+}=\mathrm{Zn}, \mathrm{Fe}^{2+}, \mathrm{Mg}$, $\mathrm{Mn}$, and $\mathrm{Ca}, \mathrm{R}^{3+}=\mathrm{Al}, \mathrm{Fe}^{3+}, \mathrm{Nb}, \mathrm{Si}$, and $\mathrm{Ti}$, and $\mathrm{x}=$ around 0.5 . The $\mathrm{Fe} / \mathrm{Zn}$ ratio of the different nigerite crystals is controlled by the initial composition of the associated spinel.
\end{abstract}

E. A. J. Burke, P. Lof and H. P. Hazebroek, Institute of Earth Sciences, Free University, De Boelelaan 1085, Amsterdam 11, Holland.

\section{Introduction}

In the course of an investigation of a number of granitic pegmatites on the island of $\mathrm{Ke}-$ miö, southwestern Finland, the rare tin mineral nigerite has been observed in the Rosendal pegmatite and in associated aplitic veins. This is the first reported occurrence of nigerite in Finland and in the Baltic Shield. The investigation forms a part of a current petrological project carried out in the Kemiö area since 1974 by staff members and students of the Free University of Amsterdam under the direction of Dr. László Westra. Klooster- man (1974) has given a review of the literature on the previously reported occurrences in Nigeria, Eastern Siberia, Portugal, Spain, and Brazil. The mineral has also been reported from China (Mineral. Abstr., 74-1926).

\section{Geological Setting}

The island of Kemiö is a part of the Svecokarelides in the Baltic Shield; it has been mapped by Seitsaari (1955) and Edelman (1973). The geology of the Svecokarelides in southwestern Finland has been described 
by Simonen (1971). The central area of the island is formed by the westernmost part of the Kemiö-Kisko leptite belt (Eskola 1914), an E-W trending zone of folded detrital, calcareous, and volcanogenic sedimentary rocks which were metamorphosed under amphibolite facies conditions. This belt has been intruded by a variety of synkinematic igneous rocks, ranging from ultrabasic to acid in composition. To the north and to the south the leptite belt is bordered by the late-kinematic potassium-rich Perniö and Hanko granites respectively. Numerous granitic pegmatites occur in a large gabbro body in the northwestern part of the island. This synkinematic intrusive body is situated to the south of the Perniö granite, with which the pegmatites may genetically be linked. The pegmatite field is geochemically characterized by the presence of Ta-Nb-Sn-Be (Volborth 1955), and the high content of Al-minerals as cordierite, sillimanite, garnet, and spinel.

\section{Occurrences and parageneses}

The Rosendal pegmatite (Peruskartta coordinates 53.25-77.15) is located about 2 $\mathrm{km}$ north of the village of Rosendal. The pegmatite has been described by Eskola (1914), Pehrman (1945, as Rosendal No. 12), and Volborth (1952). An inventory of recorded minerals has been published by Laitakari (1967, p. 218-221). The pegmatite has been quarried in the first half of this century, mainly for potassium feldspar and quartz; tantalum bearing minerals and beryl were important by-products. The pegmatite is a regular vertically dipping dike which is exposed along its east-west strike for about $150 \mathrm{~m}$; its width is $6-10 \mathrm{~m}$; the body extends vertically to a depth of a least $20 \mathrm{~m}$.

Hazebroek and Lof (1976) gave a detailed description of the internal structure, host rock relations, mineralogy, and crystallization sequence of the pegmatite. Contacts with the hornblende gabbro host rock are invariably sharp. Wall rock alteration, confined to only 0.5 to $5 \mathrm{~cm}$ from the contacts, transformed the gabbro into a chlorite-biotite-prehnite schist with a strongly developed biotite-chlorite foliation parallel to the contacts. The altered wall rock shows a strong enrichment in $\mathrm{K}$, $\mathrm{Rb}, \mathrm{Li}, \mathrm{Cs}$, and $\mathrm{Si}$, while $\mathrm{Na}$ and $\mathrm{Ca}$ are distinctly depleted. On the northern side of the pegmatite, up to $60 \mathrm{~m}$ away from the contact, the gabbro is strongly sheared. The Li-content of the gabbro on this side is unusually high (160 ppm Li $20 \mathrm{~m}$ away from the contact). In contrast to the normal zoning in most pegmatites of the area the Rosendal pegmatite shows an asymmetrically developed zoning, with a border and wall zone to the south and an aplite body on the north side. The intermediate zones and a quartz core are located between these units. The aplite body has locally been replaced by an albitemuscovite body. The asymmetrical zoning may have been caused by the strong shearing of the gabbro on the northern side of the pegmatite; reduction of the total confining pressure on the system by considerable loss of volatiles yielded the aplite body through quench crystallization; the separation into a $\mathrm{Na}_{2} \mathrm{O}$-rich melt and a fluid enriched in $\mathrm{K}_{2} \mathrm{O}$ and $\mathrm{SiO}_{2}$ was caused by resurgent boiling of a homogenous water-rich melt (Jahns and Burnham 1969).

Ginzburg et al. (1974) stated that raremetal pegmatites are formed at such depths where separation of hydrothermal solutions from residual melts becomes impossible. These hydrothermal solutions should then interact mainly with minerals formed earlier in the pegmatites. When pegmatites occur within amphibolites, and if the hydrothermal stage of the process develops very intensively, alteration of the country rocks proceeds in 
the exocontact zone of pegmatite bodies owing to the removal of alkali elements $(\mathrm{K}$, $\mathrm{Li}, \mathrm{Cs}$ ) from the pegmatites (Ginzburg et al. 1974). This has clearly been the case (also for $\mathrm{Rb}$ ) in the Rosendal pegmatite.

Nigerite occurs in the wall zone, which has a thickness of about $60 \mathrm{~cm}$. This zone mainly consists of quartz, plagioclase (An 5-27), sillimanite, muscovite, and spessartine-almandine garnet, with minor amounts of chorite, biotite, epidote, allanite, and calcite. Columbite-tantalite, hercynite spinel, chrysoberyl, tourmaline, apatite, corundum, Znbearing staurolite (up to 1.9 wt. $\% \mathrm{ZnO}$ ), and nigerite occur associated with sillimanite, garnet, and muscovite in elongated allotriomorphic aggregates which are preferentially oriented perpendicularly to the contact with the host rock; the aggregates are surrounded by a rim consisting of a fine-grained mosaic of quartz and plagioclase.

Nigerite also occurs in aplitic veins about $100 \mathrm{~m}$ south of the Rosendal pegmatite. The veins have a maximum thickness of $1 \mathrm{~m}$ and mainly consist of quartz and plagioclase (An 25), with minor amounts of garnet, muscovite, chlorite, cassiterite, apatite, gahnite spinel, and nigerite. These aplitic veins are to be considered as the fine-grained counterparts and associates of the pegmatite (Jahns and Burnham 1969).

In both occurrences nigerite is closely associated with spinel. All stages from initial to complete replacement of spinel by nigerite can be observed. Nigerite forms oriented overgrowths on spinel (Fig. 1); larger grains of nigerite often contain a core of spinel (Fig. 2); spinel-free nigerite obviously represents a stage of complete replacement. The mutual contact between intergrown nigerite and spinel is generally sharp, but gradual transitions also occur. In the pegmatite nigerite is sometimes replaced by a narrow rim of a Sn-free Fe-Al-oxide phase

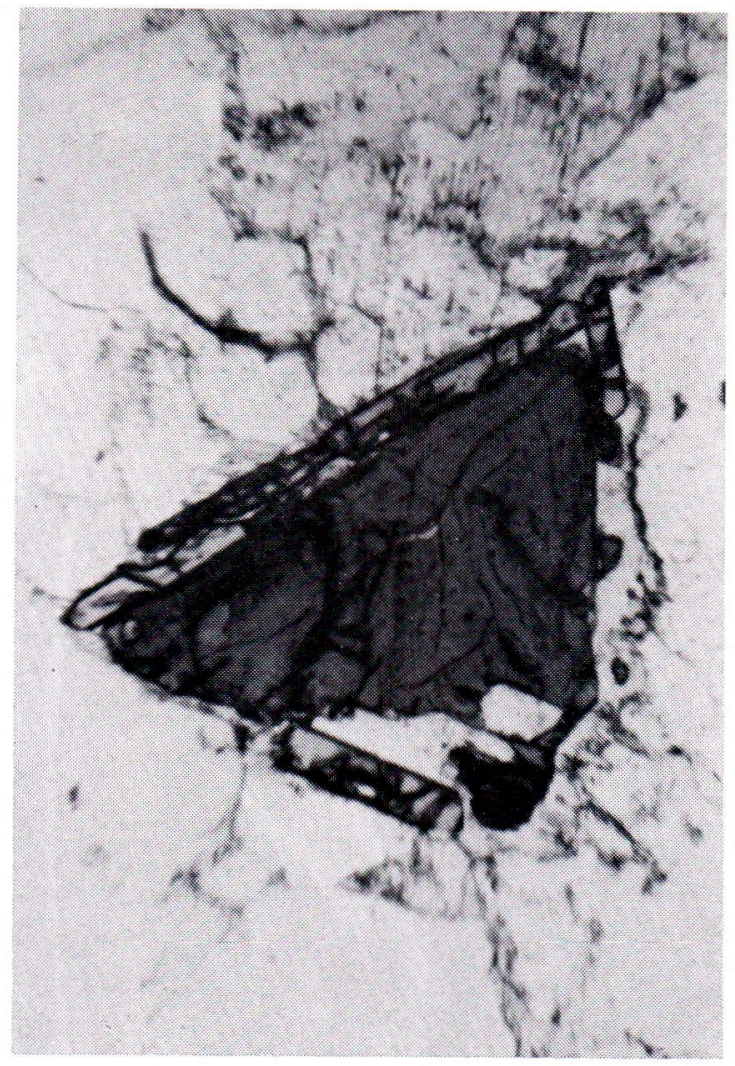

Fig. 1. Crystal of spinel (dark grey) with oriented overgrowths of nigerite (lighter grey). Specimen $\mathrm{N}-117$, aplitic veins near the Rosendal pegmatite. Transmitted light, $45 \mathrm{x}$.

which could not yet be identified. Textural relationships between the various minerals indicate that quartz, sillimanite, and spinel are older than nigerite, while garnet and corundum are younger; the transformation of spinel into nigerite must have taken place during the process of desilicification and hydrothermal activity.

\section{Optical properties}

Nigerite occurs as small subhedral to euhedral hexagonal platy crystals with a maximum diameter of $1.5 \mathrm{~mm}$. The mineral 


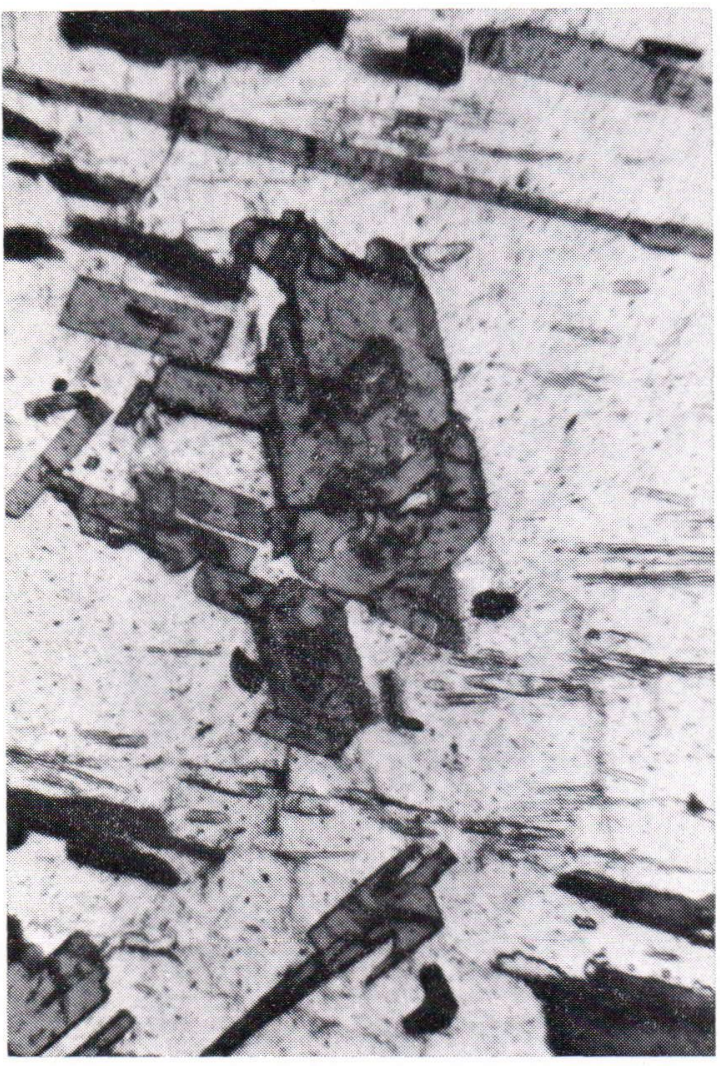

Fig. 2. Crystals of nigerite (grey) containing a core of spinel (black). Specimen HL-6, wall zone of the Rosendal pegmatite. Transmitted light, $90 \mathrm{X}$.

is uniaxial positive. A basal cleavage is weakly developed. In transmitted light nigerite shows a distinct yellowish brown colour, weak pleochroism (E pale grey-brown, O yellow-brown), high relief, and low birefringence. In reflected light in oil immersion the mineral shows a greyish colour somewhat lighter than spinel, no perceptible reflection pleochroism, a weak anisotropy, and high polishing hardness. In transmitted light the associated spinel always shows the same distinct grass-green colour, regardless of composition and $\mathrm{Fe} / \mathrm{Zn}$ ratio. The unknown Fe-Al-oxide replacing nigerite shows a more greenish colour than nigerite, and a distinctly higher birefringence.

\section{Chemical composition}

Analyses of nigerite and associated spinel have been carried out with a Cambridge Geoscan electron microprobe; the excitation potential was $20 \mathrm{kV}$. The standards used were lueshite for $\mathrm{Nb}$, diopside for $\mathrm{Si}$, olivine for $\mathrm{Mg}$, corundum for $\mathrm{Al}$, synthetic $\mathrm{TiO}$ for $\mathrm{Ti}$, synthetic SnS for $\mathrm{Sn}$, and pure elements for $\mathrm{Fe}$ and $\mathrm{Zn}$. The analytical results were corrected with a programme by Kieft and Maaskant (1969). Because of several unknown factors (presence of $\mathrm{Fe}^{2+}$ and $\mathrm{Fe}^{3+}$, $\mathrm{OH}$-content, number of cations) the analyses of nigerite had to be recalculated on the assumed presence of 8 oxygen atoms and $4 \mathrm{R}^{3+}$ atoms in the formula. Weight and atomic percentages of several nigerites are presented in Table I, along with total $\mathrm{Fe} / \mathrm{Fe}+$ $\mathrm{Zn}$ atomic ratios of the associated spinel.

The most striking result of the analyses on intergrowths of spinel and nigerite is that the chemical composition of nigerite, especially the total $\mathrm{Fe} / \mathrm{Fe}+\mathrm{Zn}$ atomic ratio, is controlled by the chemical composition of the spinel from which it was formed. The spinel in the Rosendal pegmatite is a $\mathrm{Zn}$-bearing hercynite, while the spinel in the aplitic veins is an Fe-bearing gahnite (Table I). The composition of the associated nigerite reflects the variation in the composition of the spinel, even within different intergrowths in the same sample (Fig. 3). A similar relationship between the chemical compositions of spinel and the to nigerite structurally related mineral högbomite has been demonstrated by Zakrzewski (1977).

No analyses have been published of the spinel from other occurrences of nigerite. Most authors only state that the associated spinel is gahnite. Only Bannister et al. (1947) state that the Nigerian spinel is close in composition to the ideal gahnite based on refractive index and specific gravity. This 
Table 1. Electron microprobe analyses of nigerites from Rosendal.

\begin{tabular}{|l|r|r|r|}
\hline & 1. & 2. & \multicolumn{1}{|c|}{3.} \\
\hline & & & \\
$\mathrm{MnO}$ & 0.15 & 0.15 & 0.35 \\
$\mathrm{MgO}$ & 0.50 & 0.50 & 0.60 \\
$\mathrm{ZnO}$ & 6.30 & 5.00 & 12.00 \\
$\mathrm{FeO}$ & 14.35 & 16.80 & 8.65 \\
$\mathrm{Fe}_{2} \mathrm{O}_{3}^{*}$ & 2.15 & 1.45 & 1.60 \\
$\mathrm{Al}_{2} \mathrm{O}_{3}$ & 55.80 & 55.85 & 56.15 \\
$\mathrm{TiO}_{2}$ & 0.15 & 0.35 & 0.15 \\
$\mathrm{SiO}_{2}$ & 0.10 & 0.05 & 0.30 \\
$\mathrm{Nb}_{2} \mathrm{O}_{5}$ & 0.30 & 0.45 & 0.15 \\
$\mathrm{SnO}_{2}$ & 21.00 & 18.85 & 21.30 \\
& & & \\
\hline $\mathrm{Total}$ & 100.80 & 99.45 & 101.30 \\
\hline
\end{tabular}

number of cations on basis of $8 \mathrm{O}$ and $4 \mathrm{R}^{3+}$ :

\begin{tabular}{|l|l|l|l|}
\hline & & & \\
$\mathrm{Mn}$ & 0.01 & 0.01 & 0.015 \\
$\mathrm{Mg}$ & 0.045 & 0.045 & 0.05 \\
$\mathrm{Zn}$ & 0.275 & 0.22 & 0.525 \\
$\mathrm{Fe}^{2+}$ & 0.71 & 0.835 & 0.425 \\
$\mathrm{Fe}^{3+}$ & 0.095 & 0.065 & 0.08 \\
$\mathrm{Al}$ & 3.885 & 3.91 & 3.895 \\
$\mathrm{Ti}$ & 0.005 & 0.015 & 0.005 \\
$\mathrm{Si}$ & 0.005 & 0.005 & 0.015 \\
$\mathrm{Nb}$ & 0.01 & 0.01 & 0.005 \\
$\mathrm{Sn}$ & 0.495 & 0.445 & 0.500 \\
$\mathrm{R}^{2+}$ & 1.04 & 1.11 & 1.015 \\
$\mathrm{R}^{3+}$ & 4.00 & 4.00 & 4.00 \\
$\mathrm{Sn}$ & \\
$\mathrm{Fe} / \mathrm{Fe}+\mathrm{Zn}$ Nig. & 0.495 & 0.445 & 0.500 \\
$\mathrm{Fe} / \mathrm{Fe}+\mathrm{Zn}$ Spin. & 0.745 & 0.803 & 0.490 \\
& 0.733 & 0.819 & 0.430 \\
\hline
\end{tabular}

* calculated.

1. and 2. Nigerite, Rosendal pegmatite, specimen HL-12-B.

3. Nigerite, Rosendal aplitic veins, specimen N-117.

is surprising in view of the high Fe-content (14.55 wt. ${ }^{\%} / 0 \mathrm{FeO}+\mathrm{Fe}_{2} \mathrm{O}_{3}$ ) of the associated nigerite.

The Sn-free phase replacing nigerite is essentially an Fe-Al-oxide mineral with minor amounts of $\mathrm{Zn}$ and $\mathrm{Mg}$; the low totals obtained in microprobe analyses indicate the possible presence of an element like $\mathrm{Li}$ or Be.

\section{X-ray data}

$\mathrm{X}$-ray diffraction diagrams were obtained with a Straumanis-type $114.83 \mathrm{~mm}$ diameter

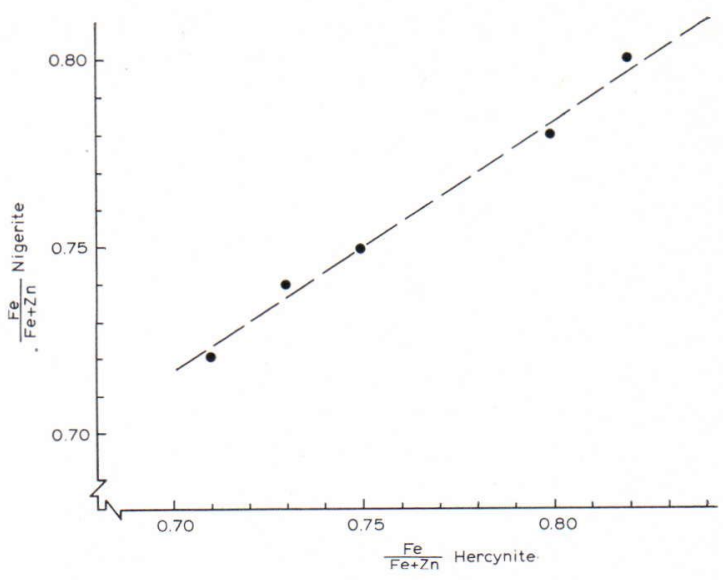

Fig. 3. Plot of total $\mathrm{Fe} / \mathrm{Fe}+\mathrm{Zn}$ atomic ratios in five intergrowths of hercynite and nigerite. Specimen HL-12-B, Rosendal pegmatite.

Debye-Scherrer camera with Mn-filtered Feradiation. The powder was drilled out of polished thin sections under the microscope and taken into rubber solution balls.

The patterns are essentially similar to that of nigerite published by Berry and Thompson (1962, p. 203-4), including all lines which could not be indexed by them on the lattice dimensions given for nigerite by Bannister et al. (1947). Berry and Thompson attributed these lines to minute inclusions. The Rosendal nigerite yields additional lines at 9.37, 3.20, and $3.09 \AA$. Peacor (1967) has shown that nigerite forms several polytypes, similar to the structurally related mineral högbomite (McKie 1963). It seems probable that the Rosendal nigerite represents a new polytype of nigerite, but single crystal studies will have to be carried out to confirm this assumption.

\section{Genetical considerations}

The occurrence of nigerite in the Rosendal pegmatite and in the Rosendal aplitic veins confirms the conditions and rules for the occurrence of nigerite as set forth by Ginzburg et al. (1963) and Kloosterman (1974). In 
the pegmatite removal of silica into the host rock caused a relative oversaturation of alumina in the pegmatite system, leading to the formation of minerals as corundum, chrysoberyl, staurolite, and spinel. The spinel reacted during this process with Sn-bearing solutions to form nigerite, which is evident from the widely varying, but similar $\mathrm{Fe} / \mathrm{Zn}$ ratio in intergrowths of both minerals. As no cassiterite has been formed Sn was not in excess in the pegmatite, which is also confirmed by the replacement of nigerite by a Sn-free oxide. The aplitic veins in contrast contain $1-2$ vol. $\%$ cassiterite; the fact that the spinel in the aplites has not been transformed completely to nigerite under conditions of excess Sn may be explained by the rapid crystallization of these rocks.

The Rosendal pegmatite is relatively rich in $\mathrm{Li}$; the average content is about $65 \mathrm{ppm} \mathrm{Li}$, with a maximum in its border and wall zones (200-700 ppm Li), while the gabbro immediately adjacent to the pegmatite even contains up to $1400 \mathrm{ppm} \mathrm{Li.} \mathrm{Although} \mathrm{this} \mathrm{peg-}$ matite is not of the true $\mathrm{Na}-\mathrm{Li}$ type, these observations confirm that hydrothermal activity in rare-metal pegmatites is accompanied by removal of alkali elements into the host rock (Ginzburg et al. 1974), and that nigerite should be formed in contact zones of granite pegmatites of the sodium-lithium type (Ginzburg et al. 1963).

Judging from the description by Pehrman (1945) the Lemnäs pegmatite (Peruskartta coordinates $50.8-78.4$, nowadays inaccessible to the general public for military reasons) should be regarded as being of the true $\mathrm{Na}-\mathrm{Li}$ type. As it contains spinel and cassiterite it seems likely that nigerite will also be found in this pegmatite.

Acknowledgements - The authors are indebted to $\mathrm{Mr}$. H. W. Nugteren for providing a specimen of the aplitic veins, and to Mr. J. Kist of the University of Amsterdam for atomic absorption analyses of $\mathrm{Li}$. Electron microprobe analyses were carried out by Mr. W. Lustenhouwer of the WACOM, a working group for analytical geochemistry subsidized by the Netherlands Organization for the Advancement of Pure Research (ZWO).

\section{References}

Bannister, F. A., Hey, M. H. and Stadler, H. P. (1947) Nigerite, a new tin mineral. Mineral. Mag. 28: 129-136.

Berry, L. G. and Thompson, R. M. (1962) X-ray powder data for ore minerals: the Peacock Atlas. Geol. Soc. Amer. Mem. 85.

Edelman, N. (1973) [Map of Fre-Quaternary rocks], 1034 Nagu. Geological Map of Finland, $1: 100000$.

Eskola, P. (1914) On the petrology of the Orijärvi region in southwestern Finland. Bull. Comm. Géol. Finlande 40. 277 p.

Ginzburg, A. I., Nazarova, A. S. and Sukhomazova, L. L. (1963) Nigerite from Siberian pegmatites. Pp. $42-46$ in New data on rare element mineralogy, ed. by A. I. Ginzburg. Con- sultants Bureau, New York.

Ginzburg, A. I., Kupriyanova, I. I. and Feldman, L. G. (1974) A model for the geological-geochemical system "granite intrusive - rare metal ore mineralization». Pp. 95-98 in $\mathrm{Me}-$ tallization Associated with Acid Magmatism, Vol. 1 ed. by M. Štemprok. Ústřední ústav geologický, Praha.

Hazebroek, H. P. and Lof, P. (1976) Petrology and mineralogy of some selected pegmatites of the Kemiö island, SW-Finland, Part II: Geology and petrology of selected pegmatites of the area between Lemnästräsket and Mattkärr. Manuscript. Free Univ. Amsterdam. 118 p. Jahns, R. H. and Burnham, C. W. (1969) Experimental studies of pegmatite genesis. I. A model 
for the derivation and crystallization of granitic pegmatites. Econ. Geol. 64: 843-864.

Kieft, C. and Maaskant, P. (1969) Quantitative microprobe analyses of silicates: a comparison of different correction methods. Abstr. Confer. Roy. Microsc. Soc., Roy. Mineral. Soc., Manchester.

Kloosterman, J. B. (1974) Nigerite in the tin-tantalum pegmatites of Amapá, Brazil. Mineral. Mag. 39: 837-846.

Laitakari, A. (1967) Suomen mineraalien hakemisto, Index of Finnish minerals with bibliography. Bull. Comm. Géol. Finlande 230. 842 p.

McKie, D. (1963) The högbomite polytypes. Mineral. Mag. 33: 563-580.

Peacor, D. R. (1967) New data on nigerite. Amer. Mineral. 52: 864-866.
Pehrman, G. (1945) Die Granitpegmatite von Kimito (S.W.-Finnland) und Ihre Minerale. Acta Acad. Aboensis, Mathem. Phys. XV.2. 84 p.

Seitsaari, J. (1955) [Map of Pre-Quaternary rocks], 2012 Perniö. Geological Map of Finland, 1: 100000 .

Simonen, A. (1971) Das finnische Grundgebirge. Geol. Rundschau 60: 1406-1421.

Volborth, A. (1952) Kemiön pegmatiitit. Manuscript. Geol. Survey Finland. 13 p.

- (1955) Das Bor in den finnischen Pegmatiten. Tschermaks Mineral. Petrog. Mitt. 5: 252-259. Zakrzewski, M. A. (1977) Högbomite from the Fe$\mathrm{Ti}$ deposit of Liganga (Tanzania). Neues Jahrb. Mineral., Monatsh. 1977: 373-380.

Manuscript received September 5, 1977. 